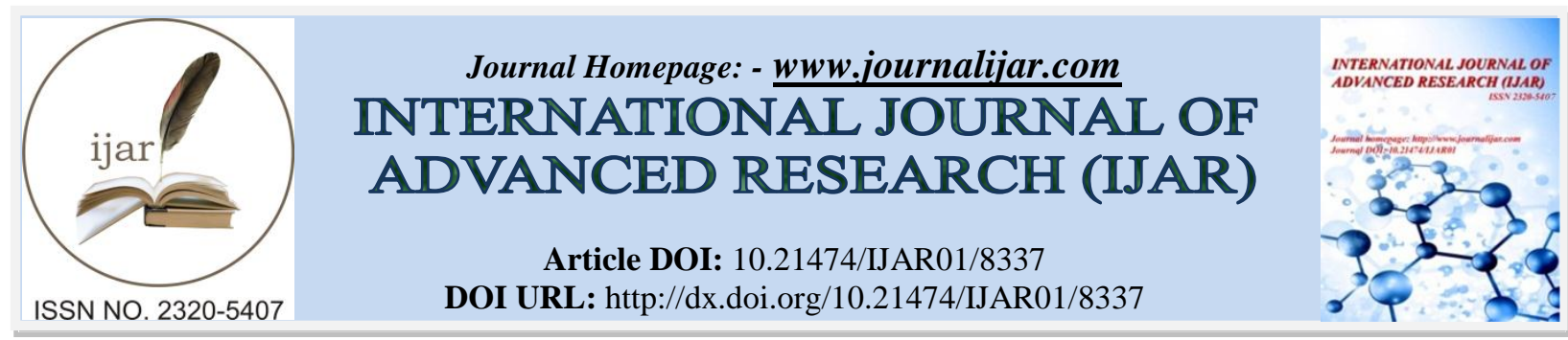

RESEARCH ARTICLE

\title{
SOCIO-DEMOGRAPHIC CHARACTERISTICS OF VENDORS AND MANUFACTURING PRACTICES OF FRESH UNPASTEURIZED FRUIT AND VEGETABLE JUICES IN KAMPALA, UGANDA.
}

Phoebe P. Kaddumukasa ${ }^{1}$, Samuel M. Imathiu ${ }^{2}$, Julius M. Mathara ${ }^{2}$ and Jesca L. Nakavuma ${ }^{3}$.

1. Department of Food Technology, Faculty of Science, Kyambogo University, Kampala, Uganda.

2. Department of Food Science and Technology, School of Food and Nutritional Sciences, Jomo Kenyatta University of Agriculture and Technology, Nairobi Kenya.

3. College of Veterinary Medicine, Animal Resources and Biosecurity, Makerere University, Kampala, Uganda.

\section{Manuscript Info}

(..........................

Manuscript History

Received: 08 November 2018

Final Accepted: 10 December 2018

Published: January 2019

Key words: -

Fresh juice, preparation, practices, storage, vending.

\section{Abstract}

Fresh juices as beverages are valued because they offer numerous health benefits to consumers. However, the manufacturing methods used in their preparation produce a great variation in terms of product quality. The aim of this study was to examine fresh juice production practices and determine the socio-demographic characteristics of vendors involved in the juice business in Kampala. A structured questionnaire was used to examine the practices of ninety juice vendors using the interview method. Findings from the study indicate that different blends of fresh juice were made with passion fruit as the main type of a single beverage. Poor manufacturing practices used in extraction of the juices were statistically significant $(p<0.05)$. Women (74\%) with low level of education dominated the production and vending of juices. Statistically significant $(\mathrm{p}<0.05)$ vending practices were observed for the following manufacturing practices namely; fruit vegetable and juice storage; sanitation of equipment, transportation of fresh produce and level of education within the food establishments. Great need in the use of good manufacturing practices by all juice vendors should be promoted and encouraged by the government and all concerned regulatory bodies in Kampala.

Copy Right, IJAR, 2018. All rights reserved.

\section{Introduction: -}

Codex Alimentarius defines juice as "unfermented ready to drink liquid, obtained from sound, mature ripe fruit or vegetables kept exclusively by physical means (FAO, 2005). Fresh fruit and vegetable juices which are credited for their health and nutritional benefits provide the human body with an abundant supply of vitamins, minerals and naturally occurring phytochemicals (Artes and Allende, 2012). The presence of these nutrients in fresh juices has led to their increased demand due to extensive consumer awareness particularly in dealing with chronic degenerative diseases (Buck, 2003). These juices which are usually nutrient dense beverages are often also consumed for their 'fresh flavor' attributes (Mahale et al., 2008; Khan et al., 2015). A range of flavors made by blending fruit and vegetable juices are now available on the market. Besides single fresh fruit or vegetable juices there is an increasing demand for juice blends due to their perceived improved quality attributes and nutritional quality (De Carvalho et al., 2007; Koutchma et al., 2016). Despite being a healthy choice for many consumers, fresh juices can often 
contribute to microbial foodborne illnesses which can be devastating particularly to the young, the elderly and immunocompromised due to their weakened immune systems (Oranusi and Wesley, 2012; Batool et al., 2013). Just like most street vended foods in developing countries, fresh juices are often prepared under unsanitary conditions exposing them to risks of contamination by both pathogenic and spoilage microorganisms (Imathiu, 2017; Imathiu, 2018). This condition is compounded by the lack of process steps that would the microorganisms to safe level (Mahale et al., 2008). Furthermore, the juices are contaminated when vendors fail to apply good manufacturing practices and personal hygiene along the processing line. For the juices that are prepared off-site, spoilage is increased when they are subjected to temperature abuse during transportation to food establishments and even when being served.

An alternative measure using pasteurization is available to eliminate the pathogens and reduce spoilage microorganisms. Pasteurization of juices could be an alternative but consumer preferences for fresh beverages emphasize that the products supplied in the market be unpasteurized which increases the demand for these products (Torres-Vitela et al., 2013). Reports of several food borne illnesses caused by consumption of contaminated fresh juices have been made contributing to the global burden of morbidity and mortality (Braide et al., 2012; TorresVitela et al., 2013; Simforian et al., 2015; Koutchma et al., 2016).

Reports of morbidity and mortality arising from the consumption of juices prepared using unsatisfactory manufacturing practices have been cited (Torres-Vitela et al., 2013). Use of unsatisfactory practices in the preparation of street foods in Uganda has been done however juices were only mentioned (Muyanja et al., 2011). A gap exists in the knowledge of who is involved, and the practices used in the preparation and vending of juices. This study therefore was carried out to establish demographic characteristics of vendors and vending practices of fresh unpasteurized fruit and vegetable juices and their blends sold in Kampala, Uganda.

\section{Materials and Methods: - \\ Study area}

The study was conducted in Kampala city, Uganda $\left(00^{\circ} 19^{\prime} \mathrm{N}, 32^{\circ} 35^{\prime} \mathrm{E}\right)$ from November 2014 to October 2015 Kampala hosts a population of about 30 million people distributed in five divisions within the city. Three out of the five divisions were selected because of the many retail outlets supplying fresh unpasteurized juices and the large populations supporting these outlets. The selected divisions included were: Kampala central, Kawempe and Nakawa.

\section{Study design and participant selection}

A cross sectional research design was used to obtain sociological data. A total of 90 juice vendors with 30 participants from each division were selected from food establishments within Kampala. Consent to carry out the study was obtained from Kampala City Council Authority (KCCA). Selection was based on participants' availability, willingness to take part in the study, and to give accurate information. A structured questionnaire comprising of closed and open ended questions was first pre-tested on 30 vendors in Nateete division. Information on the types of juices made, extraction methods, sites of production, sources of fruits and vegetables, storage facilities, sanitation of juice equipment and utensils; and demographic characteristics of vendors was obtained using the interview method.

\section{Types of food establishments}

Food establishments used in this study included those in the markets, take-aways and restaurants selling fresh unpasteurized juices. In the markets, the food establishments were partitioned into cubicles built of concrete but with open spaces at the top. Local foods were prepared on site and served with fresh juices or other beverages as the consumers requested. The take-aways were complete units with provision for sitting to eat and/or drink or carry away as consumers desired. Snacks and fast foods together with juice or other beverages were sold in these takeaways. Restaurants were also complete units with provision to sit and eat the foods that were prepared. Local foods prepared on site were served together with fresh juices and/or other beverages.

\section{Data analysis}

Data obtained during the study were reviewed during and after collection. Variables from the respondents were coded, classified and tabulated. Statistical package for social scientists (SPSS) version 21 was used to analyze the data. Categorical variables were analyzed using frequencies and the Shapiro Wilk test was used to assess whether scores were normally distributed. Relationships of variables between juice types and processing practices were 
established using cross tabulations and the Chi-square test. Relationships of variables across the food establishments were established using the Kruskal Wallis test. The level of significance was set at 95\%, with a P-value less than 0.05 considered significant.

\section{Results: -}

\section{Sample characteristics}

A Shapiro Wilk test $(\mathrm{p}<0.05)$ and a visual inspection of their histograms, normal Q-Q plots and box plots showed that juice types, vending practices and demographic characteristics were skewed and kurtotic across the food establishments.

\section{Survey of socio-demographic characteristics of juice vendors}

Findings from the socio-demographic characteristics of juice vendors indicated that women (77\%) were the main vendors of fresh unpasteurized juices with a minority of men (23\%). However, non-significant differences ( $\mathrm{p}>0.05)$ in gender were observed (Table 1). Significant differences $(\mathrm{p}=0.000)$ in vendors' education were observed within the food establishments. More than half (52\%) of the vendors had low education which probably implies that knowledge of the use of good manufacturing practices was very poor.

Table 1:-Demographic characteristics of fresh juice vendors within the food establishments

\begin{tabular}{|c|c|c|c|c|c|}
\hline Type of Food Establishment & Market $(n=30)$ & $\begin{array}{l}\text { Take-away } \\
(\mathrm{n}=30)\end{array}$ & $\begin{array}{l}\text { Restaurant } \\
(\mathrm{n}=30)\end{array}$ & Total $(\mathrm{n}=90)$ & P-value \\
\hline \multicolumn{6}{|c|}{ Demographic characteristics of juice vendors } \\
\hline \multicolumn{6}{|l|}{ Characteristic } \\
\hline \multicolumn{6}{|l|}{ Gender of juice vendors } \\
\hline Male & $6(20 \%)$ & $9(30 \%)$ & $6(20 \%)$ & $21(23.3 \%)$ & \\
\hline Female & $24(80 \%)$ & $21(70 \%)$ & $24(80 \%)$ & $69(76.7 \%)$ & 0.575 \\
\hline \multicolumn{6}{|l|}{$\begin{array}{l}\text { Education levels of juice } \\
\text { vendors }\end{array}$} \\
\hline No Education & $9(30 \%)$ & $3(10 \%)$ & $13(43.3 \%)$ & $25(27.8 \%)$ & \\
\hline Primary & $11(36.7 \%)$ & $2(6.7 \%)$ & $9(30 \%)$ & $22(24.4 \%)$ & \\
\hline O-Level & $5(16.7 \%)$ & 0 & $2(6.7 \%)$ & $7(7.8 \%)$ & \\
\hline A-level & $3(10 \%)$ & $11(36.7 \%)$ & $5(16.7 \%)$ & $19(21.1 \%)$ & \\
\hline Tertiary & $1(3.3 \%)$ & $10(33.3 \%)$ & $1(3.3 \%)$ & $12(13.3 \%)$ & \\
\hline University & $1(3.3 \%)$ & $4(13.3 \%)$ & 0 & $5(5.6 \%)$ & $0.000^{*}$ \\
\hline
\end{tabular}

\section{Statistically Significant at $P<0.05$ Or 0.001}

\begin{tabular}{|l|l|l|l|l|}
\hline Type of juice & $\begin{array}{l}\text { Passion fruit } \\
(\mathbf{n = 4 2})\end{array}$ & Blends (n=48) & Total (n=90) & p-value \\
\hline Characteristic & & & & \\
\hline Manual extraction & & $22(45.8 \%)$ & $56(62.2 \%)$ & \\
\hline Yes & $34(81 \%)$ & $26(54.2 \%)$ & $34(37.8 \%)$ & $0.001^{*}$ \\
\hline No & $8(19 \%)$ & & & $34(37.8 \%)$ \\
\hline Mechanical extraction & & $26(54.2 \%)$ & $56(62.2 \%)$ & $0.001^{*}$ \\
\hline Yes & $8(19 \%)$ & $22(45.8 \%)$ & & \\
\hline No & $34(81 \%)$ & & & $68(75.6 \%)$ \\
\hline Site of juice processing & & & $22(24.4 \%)$ & 1.000 \\
\hline Produced at food establishment & & $36(75 \%)$ & & \\
\hline Yes & $32(76.2 \%)$ & $12(25 \%)$ & $22(24.4 \%)$ & \\
\hline No & $10(23.8 \%)$ & & $68(75.6 \%)$ & 1.000 \\
\hline Produced at home & & $12(25 \%)$ & & \\
\hline Yes & $10(23.8 \%)$ & $36(75 \%)$ & & \\
\hline No & $32(76.2 \%)$ & & & \\
\hline Addition of ice to the juice & & & & \\
\hline
\end{tabular}




\begin{tabular}{|l|l|l|l|l|}
\hline Yes & $7(16.7 \%)$ & $7(14.6 \%)$ & $14(15.6 \%)$ & \\
\hline No & $35(83.3 \%)$ & $41(85.4 \%)$ & $76(84.4 \%)$ & 1.000 \\
\hline
\end{tabular}

Table 2:- Methods and sites of preparation of Passion fruit juice and blends

From the survey, passion fruit was the most common single juice consumed in Kampala. However, more than half of the juices encountered in the study were passion fruit blends (Table 2). Non significant differences ( $>0.05)$ in types of juice prepared within the food establishments were observed.

Results indicated that over $60 \%$ of the juices were extracted using the manual method while $37.8 \%$ were prepared mechanically (Table 2). Significant differences $(\mathrm{p}=0.001)$ in method of extraction were observed in the establishments visited. Approximately $76 \%$ of the juices were made at the food establishments where the juice was sold. A smaller percentage (24\%) of the juices were prepared at a different location and then brought to the food establishment (Table 2). Non significant differences ( $>0.05$ ) in type of juices made were observed between the sites of juice preparation. Eighty-four percent of the vendors did not add ice to the fresh juices they served while 16\% carried out this practice. The practice of addition of ice cubes to the juices was not significantly different $(p>0.05)$ for the two types of juice products.

Table 3:-Quantities of juice sold vs types of juices and establishments

\begin{tabular}{|l|l|l|l|l|l|}
\hline $\begin{array}{l}\text { Quantity of glasses of juice sold } \\
\text { per day }\end{array}$ & $\begin{array}{l}\text { Group 1 10-49 } \\
(\mathrm{n}=47)\end{array}$ & $\begin{array}{l}\text { Group II 50-89 } \\
(\mathrm{n}=42)\end{array}$ & $\begin{array}{l}\text { Group III 90- } \\
129(\mathrm{n}=1)\end{array}$ & Total (n=90) & $\begin{array}{l}\mathrm{p}- \\
\text { value }\end{array}$ \\
\hline Type of juice & & & & & \\
\hline Passion fruit juice & $23(48.9 \%)$ & $18(42.9 \%)$ & 0 & $41(45.6 \%)$ & \\
\hline Passion fruit juice blends & $24(51.1 \%)$ & $24(57.1 \%)$ & $1(100 \%)$ & $48(53.3 \%)$ & 0.48 \\
\hline Type of establishment & & & & & \\
\hline Market & $20(42.6 \%)$ & $10(23.8 \%)$ & 0 & $30(33.3 \%)$ & \\
\hline Take-away & $16(34 \%)$ & $14(33.3 \%)$ & 0 & $30(33.3 \%)$ & \\
\hline Restaurant & $11(23.4 \%)$ & $18(42.8 \%)$ & $1(100 \%)$ & $30(33.3 \%)$ & $0.04 *$ \\
\hline
\end{tabular}

* Statistically significant at $\mathrm{p}<0.05$

Fifty-three percent $(n=90)$ of the juices sold in the food establishments were blends while $46 \%$ were made of passion fruit juice only (Table 3). Juices in the markets and restaurants were mainly sold in the morning or at lunchtime when food was served. For the fast food establishments juices were sold with the snacks throughout the day. Nonsignificant differences $(p>0.05)$ in types of juices sold within the food establishments were observed. Quantities of juice sold within the food establishments was significantly different $(\mathrm{p}<0.05)$ possibly because of consumer preferences within the city.

Majority $(83.3 \%)(n=90)$ of the fruits and vegetables obtained for juice preparation were from the open market with only a small portion from middlemen. Non-significant differences ( $>0.05)$ in sources of fruits and vegetables purchased for juice preparation were observed within the different establishments (Table 4). Fruits and vegetables were mainly transported by bicycles and wooden carts to the food establishments. Significant differences $(\mathrm{p}=0.01)$ in transport used for transfer of fruits or vegetables from markets to food establishments were observed.

Nearly half (49\%) of the fruits and vegetables used for juice preparation were stored in baskets with $27 \%$ of the produce placed on shelves. Furthermore, storage of fresh produce in baskets and shelves provided limited shelf life and exposure to vermin. Significant differences $(\mathrm{p}=0.000)$ in fresh produce storage was observed across the food establishments.

Findings indicated that over half of the vendors used refrigerators to store the juice while a minority used dispensing equipment (Table 4). Significant differences $(\mathrm{p}=0.000)$ in juice storage were observed across the food establishments with dispensers mainly used in the take-aways and refrigerators in the markets and restaurants. 
Findings from the study indicate that $87 \%(\mathrm{n}=90)$ of vendors cleaned their utensils once a day while a very small percentage washed them right after use. However non significant differences $(p>0.05)$ in sanitation of utensils was observed across all food establishments.

Table 4:-Fresh juice manufacturing practices within the food establishments

\begin{tabular}{|c|c|c|c|c|c|}
\hline $\begin{array}{l}\text { Type of food } \\
\text { establishment }\end{array}$ & $\begin{array}{l}\text { Market } \\
(\mathbf{n}=30)\end{array}$ & $\begin{array}{l}\text { Take-away } \\
(\mathbf{n}=30)\end{array}$ & $\begin{array}{l}\text { Restaurant } \\
(\mathbf{n}=30)\end{array}$ & Total $(n=90)$ & p-value \\
\hline \multicolumn{6}{|c|}{ Sources, transportation and storage of fruits } \\
\hline \multicolumn{6}{|l|}{$\begin{array}{l}\text { Sources of fruits and } \\
\text { vegetables }\end{array}$} \\
\hline Open market & $29(96.7 \%)$ & $23(76.7 \%)$ & $23(76.7 \%)$ & $75(83.3 \%)$ & \\
\hline Farmers & 0 & 0 & $7(23.3 \%)$ & $7(7.8 \%)$ & \\
\hline Middlemen & $1(3.3 \%)$ & $7(23.3 \%)$ & 0 & $8(8.9 \%)$ & \\
\hline Home garden & 0 & 0 & 0 & 0 & 0.059 \\
\hline \multicolumn{6}{|l|}{$\begin{array}{l}\text { Transportation of } \\
\text { fruits/vegetables }\end{array}$} \\
\hline Bicycle & $5(16.7 \%)$ & $8(26.7 \%)$ & $14(46.7 \%)$ & $27(30 \%)$ & \\
\hline Cart & 0 & 0 & $11(36.7 \%)$ & $11(12.2 \%)$ & \\
\hline Motorcycle & $19(63.3 \%)$ & $5(16.7 \%)$ & $5(16.7 \%)$ & $29(32.2 \%)$ & \\
\hline Vehicle & $6(20 \%)$ & $16(53.3 \%)$ & 0 & $22(24.4 \%)$ & \\
\hline Carried by vendor & 0 & $1(3.3 \%)$ & 0 & $1(1.1 \%)$ & $0.011 *$ \\
\hline \multicolumn{6}{|c|}{ Storage of fruits/vegetables } \\
\hline Basket & $16(53.3 \%)$ & $2(16.7 \%)$ & $24(80 \%)$ & $42(46.7 \%)$ & \\
\hline Floor & $2(6.7 \%)$ & $4(13.3 \%)$ & 0 & $6(6.7 \%)$ & \\
\hline Shelf & $9(30 \%)$ & $11(36.7 \%)$ & $6(20 \%)$ & $26(28.9 \%)$ & $0.000^{*}$ \\
\hline Refrigerator & $3(10 \%)$ & $13(43.3 \%)$ & 0 & $16(17.8 \%)$ & \\
\hline \multicolumn{6}{|l|}{ Storage of juices } \\
\hline Plastic buckets & $2(6.7 \%)$ & 0 & $7(23.3 \%)$ & $9(10 \%)$ & \\
\hline Plastic jerry cans & $8(26.7 \%)$ & 0 & $3(10 \%)$ & $11(12.2 \%)$ & \\
\hline Refrigerators & $17(56.7 \%)$ & $7(23.3 \%)$ & $16(53.3 \%)$ & $40(44.4 \%)$ & \\
\hline Dispensers & $3(10 \%)$ & $23(76.7 \%)$ & $4(3.3 \%)$ & $30(33.3 \%)$ & $0.000^{*}$ \\
\hline \multicolumn{6}{|c|}{ Sanitation of juice processing equipment } \\
\hline \multicolumn{6}{|l|}{ Cleaning of utensils } \\
\hline Right after use & $5(16.7 \%)$ & $4(13.3 \%)$ & $3(10 \%)$ & $12(13.3 \%)$ & \\
\hline Once per day & $25(83.3 \%)$ & $26(86.7 \%)$ & $27(90 \%)$ & $78(86.7 \%)$ & \\
\hline \multicolumn{6}{|c|}{ Cleaning of dispenser } \\
\hline Right after use & $2(6.7 \%)$ & 0 & 0 & $2(2.2 \%)$ & \\
\hline Once per day & 0 & $14(46.7 \%)$ & $4(13.3 \%)$ & $18(20 \%)$ & \\
\hline Not used & $28(93.3 \%)$ & $16(53.3 \%)$ & $26(86.7 \%)$ & $70(77.8 \%)$ & $0.001 *$ \\
\hline
\end{tabular}

* statistically significant at $\mathrm{p}<0.05$ or 0.001

\section{Discussion: -}

The higher percentage of female juice vendors obtained in this study could possibly be due to their desire to supplement the family's income (Table 1). These results are in agreement with earlier findings obtained in Kampala, Jinja and Masaka (Muyanja et al., 2011). Studies conducted in different parts of the world have also cited women as the main stakeholders of street vended foods (Mitullah, 2003; Worku, 2011; Gabriel, 2014). However, juice vending in Dar es Salaam city, Tanzania and major cities in India is mainly done by men (54\%) (Bhowmik, 2012; Simforian et al., 2015).

Vendors in the permanent food establishments in particular the take-aways were more educated than those in the markets and restaurants. The differences in education could possibly be due to location of these take-aways near universities and in the centre of the city attracting more educated clientele. Furthermore, the operation of some equipment in the take-aways required vendors with skills which possibly led to hire of more educated labourers. They probably observed better hygienic practices and attracted more clientele. 
High consumption and preparation of passion fruit juice may possibly be due to its aroma, taste and availability all year round (Nyanzi et al., 2005). Consumer preference for blends could be due to the better flavor and nutritional quality. In Dar es salaam city, production of juice blends has been cited (Simforian et al., 2015). Juice blending is believed to increase the nutritional value of the product because of increased enzymes, nutrients and bioactive components (Carvalho et al., 2007; Lima et al., 2009).

Manual extraction was the most frequent method used possibly due to the types of juices prepared in the establishments. Most of the juices did not require equipment for preparation. The mechanical method was mainly used when two or more fruit or vegetables required blending. Manual and mechanical methods of juice extraction have been reported as processing methods in juice production (Simforian et al., 2015).

Quantities of juice sold depended on consumer preferences, cost of juice per glass, types of juices sold and general sanitation of the food establishment. Similar types of juices were available within the food establishments.

The transportation of juices from the site of preparation to the food establishment without the use of any cold chain brought out the concern for temperature fluctuations in the juice products. The use of inappropriate temperature and long distance between preparation and serving of food products is cited as a possible source of contamination for juice products (Hoseinzedah et al., 2012).

Purchase of fruits and vegetables from the open market could possibly be due to the delivery of fresh produce to the open markets, from where retailers and middlemen bought the produce to sell in other markets, shops or food establishments (USAID-KCHP, 2014). Secondly the open market allowed for bargaining or haggling of prices before purchase while middlemen had fixed prices for their produce. Similar reports of purchase of fruits and vegetables from the open market have been observed (Ketema et al., 2008).

Use of bicycles and wooden carts within the markets was probably due to the fact that produce needed only to be moved from one point to another, while for the take-aways and bigger restaurants more sustainable means of transportation like motorcycles and vehicles was required because they were located at greater distances.

Within the markets, food establishments that dealt in juice products possibly had easy access to fresh produce and could purchase the fruits and vegetables whenever need arose. Take-aways and some of the restaurants which were at greater distances than the markets possibly required better storage of the fruits and vegetables to save time and money thus the use of refrigerators. Storage of fruits and vegetables in refrigerators was used by vendors in the more permanent establishments. The reverse for fresh produce storage on shelves $50 \%$ and $22.2 \%$ in baskets has been reported (Ketema et al., 2008).

Preference for use of refrigerators for storage could possibly be attached to the cost of purchasing the dispenser and yet the refrigerator was used to store other food products as well as the juices. Storage of juices in plastic buckets or jerry cans allowed for temperature fluctuations during transportation to the food establishment.

Cleaning of utensils and equipment once a day could possibly be due to vendors' efforts to save water and money hence the use of the same type of rinsing water throughout the day (Muyanja et al., 2011). The use of the same type of rinse water could possibly give opportunity for cross contamination to occur from the utensils to the finished product. For the food establishments that used dispensers, majority cleaned them once a day possibly when the juice was finished.

\section{Conclusion: -}

From the findings, passion fruit was the most common single juice made; with a variety of blends of different fruits or vegetables. Women with poor manufacturing practices and low education dominated the fresh juice vending business in Kampala. Fruits and vegetables used for juice preparation were purchased by the vendors from the open markets and stored in baskets and on shelves. Storage of fresh produce in baskets limited their shelf life and exposed fruits and vegetables to vermin, a likely source of contamination for the juice products. From the findings, fresh juices sold in Kampala were most often stored in refrigerators while dispensers were found only in the city centre. There is therefore need for training and increased awareness of the stakeholders in the fresh beverage value chain in 
the use of good manufacturing practices. In addition, food laws should be enforced as well as routine monitoring and evaluation of the beverages sold within the city in particular fresh juices.

\section{Acknowledgements: -}

The authors acknowledge the financial support of DAAD/RUFORUM for funding the study. Thanks to all the fresh juice vendors for their permission and for the food establishments who took time to participate in the study.

\section{References: -}

1. Addisu, D., Letebrhan, K., and Siyane, S. (2016). Isolation and Identification of Bacteria from Fresh Fruit Juice Prepared in Cafeterias and Restaurants, Axum Town. International Journal of Integrative Sciences, Innovation, and Technology, V(2), 5-10.

2. Artes, F., and Allende, A. (2012). Minimal processing of fresh fruit, vegetables and juices. In V. M. Gómez-López (Ed.), Decontamination of Fresh and Minimally Processed Produce (pp. 583- 597). Oxford, UK: Wiley-Blackwell. http://doi.org/10.1002/9781118229187

3. Batool, S. A., Tahir, S. S., Rauf, N., and Kalsoom, R. (2013). Microbiological analysis of pasteurized and fresh fruit juice sold in Rawalpindi of Pakistan. Bangladesh Journal of Scientific and Industrial Research, 48(3), $185-192$.

4. Bhowmik, S. K., and Debdulal, S. (2012). Street Vending in Ten Cities in India (pp. 1-174). Mumbai, India.

5. Braide, W., Oranunsi, S.U and Otali, C. C. (2012). Microbiological status of processed fruit juice sold in the commercial city of Onitsha. Biological Science, 1(3), 25-30.

6. Buck, J. W., Walcott, R. R. and Beauchat, L. R. (2003). Recent Trends in Microbiological Safety of fruits and vegetables. Plant Health Progress, (January). http://doi.org/10.1094/PHP-2003-0121-01-RV

7. De Carvalho, J. M., Maia, G.A., De Figueiredo, R.W., De Brito, E.S. and Rodrigues, S. 2007. Storage Stability of a stimulant coconut water-cashew apple juice beverage. Journal of food processing and preservation. Vol 31. Pp 178189

8. FAO, 2005. General Standard for fruit juices and nectars. Codex Alimentarius Commision. www.codexalimentarius.org/..../standards/..../CXS247

9. Gabriel, S. C. (2014). An ethical assessment of street food vending in Lusaka's Central Busines District. University of Zambia.

10. Imathiu, S., (2017) Street vended foods: potential for improving food and Nutrition security or a Risk factor for foodborne diseases in developing countries? Current Research in Nutrition and Food Science Vol 5(2) pp 55-65.

11. Imathiu, S. 2018. Quantitative Microbiological Risk Assessment of two street foods sold in a Kenyan Town with Regard to Salmonella Contamination. Current Research in Nutrition and Food Science Vol 6 (1) pp 41-50.

12. Khan, M. M., Islam, T., Mehadi, M., Chowdhury, H., and Alim, S. R. (2015). Assessment of microbiological quality of some drinks sold in the streets of Dhaka University Campus in Bangladesh. International Journal of Food Contamination, 2(4), 0-4. http://doi.org/10.1186/s40550-015-0010-6

13. Koutchma, T., Popovic, V., Ros-polski, V., and Popielarz, A. (2016). Effects of Ultraviolet Light and High-Pressure Processing on Quality and Health-Related Constituents of Fresh Juice Products. Comprehensive Reviews in Food Science and Food Safety, 15, 844-867. http://doi.org/10.1111/1541-4337.12214

14. Lima, S., Maia, G. A., Sousa, P. H. M. De, Prado, G. M., and Rodrigues, S. (2009). Storage stability of a stimulant coconut water - acerola fruit juice beverage. International Journal of Food Science and Technology, 44, $1445-1451$. http://doi.org/10.1111/j.1365-2621.2009.01977.x

15. Mahale, D. P., Khade, R. G., and Vaidya, V. K. (2008). Microbiological Analysis of Street Vended Fruit Juices from Mumbai City, India. Internet Journal of Food Safety, 10, 31-34.

16. Mitullah. V, W. (2003). Street vending in African cities: A synthesis of empirical findings from Kenya, Cote D'ivoire, Ghana, Zimbabwe, Uganda and South Africa (pp. 1-20). Nairobi.

17. Muyanja, C., Nayiga, L., Brenda, N., and Nasinyama, G. (2011). Practices, knowledge and risk factors of street food vendors in Uganda. Food Control, 22(10), 1551-1558. http://doi.org/10.1016/j.foodcont.2011.01.016

18. Nyanzi, S. A., Carstensen, B., and Schwack, W. (2005). A comparative study of fatty acid profiles of Passiflora seed oils from Uganda. Journal of the American Oil Chemists' Society, 82(1), 41-44. http://doi.org/10.1007/s11746-0051040-2

19. Oranusi, U. S., and Braide, W. (2012). A study of microbial safety of ready-to-eat foods vended on highways: Onitsha-Owerri, south east. International Research Journal of Microbiology, 3(February), 66-71.

20. Simforian, E., Nonga, H. E., and Ndabikunze, B. K. (2015). Assessment of microbiological quality of raw fruit juice vended in Dar es Salaam city, Tanzania. Food Control, 57, 302-307. http://doi.org/10.1016/j.foodcont.2015.04.033

21. Tsige Ketema, Gaddisa Tsegaye, and B. Ketema. (2008). Microbiological safety of fruit juices served in cafes/restaurants, jimma town, southwest Ethiopia. Ethiopian Journal of Health Sciences, 18(3), 1-6 
22. Torres-Vitela, M. D. R., Gómez Aldapa, C. A., Cerna-Cortes, J. F., Villarruel-López, A., Rangel-Vargas, E., and CastroRosas, J. (2013). Presence of indicator bacteria, diarrhoeagenic Escherichia coli pathotypes and Salmonella in fresh carrot juice from Mexican restaurants. Letters in Applied Microbiology, 56(3), 180-185. http://doi.org/10.1111/lam.12030

23. USAID-KHCP, Export Promotion Council Limited, E. H. L. (2014). Passion fruit: Market research on the East African Community markets of Uganda and Rwanda (pp. 1-20). 